\title{
Kenaf (Hibiscus cannabinus) and Cowpea (Vigna unguiculata) as Sugarcane Cover Crops
}

\author{
Charles L. Webber III ${ }^{1}$, Paul M. White Jr. ${ }^{1}$, Caleb Dalley ${ }^{2}$, Eric C. Petrie ${ }^{1}$, Ryan P. Viator ${ }^{3} \&$ James W. Shrefler $^{4}$ \\ ${ }^{1}$ USDA, Agriculture Research Service, Sugarcane Research Unit, Houma, LA, USA \\ ${ }^{2}$ North Dakota State University Hettinger Research Extension Center, Hettinger, ND, USA \\ ${ }^{3}$ Calvin Viator, Ph.D. and Associates, LLC, Thibodaux, LA, USA \\ ${ }^{4}$ Oklahoma State University, Division of Agriculture Sciences and Natural Resources, Cooperative Extension \\ Service, Durant, OK, USA \\ Correspondence: Charles L. Webber III, USDA, Agriculture Research Service, Sugarcane Research Unit, Houma, \\ LA, 70360, USA. E-mail: chuck.webber@ars.usda.gov
}

Received: May 9, $2016 \quad$ Accepted: June 15, $2016 \quad$ Online Published: July 15, 2016
doi:10.5539/jas.v8n8p13
URL: http://dx.doi.org/10.5539/jas.v8n8p13

\begin{abstract}
A Louisiana sugarcane field is typically replanted every four years due to declining yields, and, although, it is a costly process, it is both necessary and an opportunity to maximize the financial return during the next four year cropping cycle. Fallow planting systems (FPS) during the fallow period prior to replanting sugarcane have the potential to influence not only the following sugarcane crop, but the economics of the production system as a whole. A 2 year experiment was conducted at the USDA, ARS, Sugarcane Research Unit at Houma, LA to determine the impact of unique FPS on sugarcane production. The experiment included seven treatments; two cover crops, kenaf (Hibiscus cannabinus L.) and cowpeas (Vigna unguiculata L. Walp.), three FPS harvest treatments for each FPS crop, and a control. The experiment had four replications. Kenaf was selected as a potential cover crop due to interest in its commercial by-products and cowpea was selected due to its potential to facilitate climate friendly soils. The kenaf and cowpeas were planted on 8 May 2013. The three FPS harvest treatments included the removal of the FPS crop at 50 days after planting (DAP), the removal of the harvested FPS crop at 100 DAP, and lastly, cutting the FPS crop at 100 DAP and incorporating the plant material into the soil prior to sugarcane planting. The control treatment did not have a cover crop. Unlike kenaf, the cowpea leaf, fresh and dry weight yields (50 DAP), 19.4 and $2.5 \mathrm{mt} / \mathrm{ha}$, respectively, decreased to 17.0 and $2.4 \mathrm{mt} / \mathrm{ha}$ (100 DAP). Although the sugarcane total recoverable sucrose (TRS) $(\mathrm{kg} / \mathrm{mt}$ ) was greater with the kenaf cover-crop treatment 50 DAP $(120 \mathrm{~kg} / \mathrm{mt})$ compared to the cowpea treatment $50 \mathrm{DAP}(111 \mathrm{~kg} / \mathrm{mt})$ and the cowpea $100 \mathrm{DAP}$ with the residue incorporated $(112 \mathrm{~kg} / \mathrm{ha})$, none of the FPS crop treatments were significantly better or worse than the control (no cover crop). The average values for the sugarcane production factors across all treatments were 95,700 stalks/ha (millable stalks), $112 \mathrm{mt} / \mathrm{ha}$ (sugarcane yield), $114 \mathrm{~kg} / \mathrm{mt}$ (sugar yield per metric ton of sugarcane), and $12,841 \mathrm{~kg} / \mathrm{ha}$ (sugar yield per hectare). The results demonstrate the potential use of these alternative cover crops during the fallow period prior to planting sugarcane without adversely affecting the plant cane yields.
\end{abstract}

Keywords: cover crops, cowpea, kenaf, plant partitioning, rotational crops, sugar, sugarcane, total recoverable sucrose, yield

\section{Introduction}

Louisiana sugarcane fields are typically replanted every four years due to declining yields, and, although, it is a costly process, it is both necessary and an opportunity to maximize the financial return during the next four year cropping cycle. Planting a cover crop during the fallow period prior to planting sugarcane has the potential to influence not only the following sugarcane crop, but the economics of the production system as a whole.

\subsection{Kenaf}

Kenaf (Hibiscus cannabinus L.) is a warm season, annual fiber crop in the same family as cotton (Gossypium hirsutum L., Malvaceae) and okra (Abelmoschus esculentus L., Malvaceae) that can be successfully produced in a various areas of the United States, particularly in the southern states (Webber \& Bledsoe, 1993). Once it was 
determined that kenaf was well suited for production in the US, research was initiated to maximize US kenaf yields. As a result, scientists successfully developed high-yielding anthracnose-resistant cultivars, cultural practices, and harvesting machinery that increased fiber yields (Nieschlag et al., 1960; White et al., 1970; Wilson et al., 1965). In the 1950s and early 1960s, in a quest to identify alternative crops for paper production, the USDA determined that kenaf would be a suitable crop for this purpose. It was determined that kenaf was an excellent cellulose fiber source for a large range of paper products (newsprint, bond paper, and corrugated liner board). It was also determined that pulping kenaf required less energy and chemical inputs for processing than standard wood sources (Nelson et al., 1962). Research in 1990s demonstrated the plant's suitability for use in building materials (particle boards of various densities, thicknesses, with fire and insect resistance), adsorbents, textiles, livestock feed, and fibers in new and recycled plastics (injected molded and extruded) (Webber \& Bledsoe, 1993).

And, although, kenaf is usually considered a fiber crop, the entire kenaf plant, stalk (core and bark), and leaves, can be used as a livestock feed (Webber et al., 2002). Research indicates that it has high protein content (Clark \& Wolff, 1969; Killinger, 1969). Crude protein in kenaf leaves ranged from $14 \%$ to $34 \%$ (Killinger, 1969; Suriyajantratong et al., 1973; Swingle et al., 1978; Webber, 1993), stalk crude protein ranged from $2 \%$ to $12 \%$ (Swingle et al., 1978; Webber, 1993), and whole-plant crude protein ranged from 6\% to 23\% (Killinger, 1969; Swingle et al., 1978; Webber, 1993). Kenaf can be ensilaged effectively, and it has satisfactory digestibility with a high percentage of digestible protein (Wing, 1967). Digestibility of dry matter and crude proteins in kenaf feeds ranged from $53 \%$ to $58 \%$ and $59 \%$ to $71 \%$, respectively (Wing, 1967; Suriyajantratong et al., 1973; Swingle et al., 1978). Kenaf meal, used as a supplement in a rice ration for sheep, compared favorably with a ration containing alfalfa meal (Suriyajantratong et al., 1973). It has also been determined that chopped kenaf ( $29 \%$ dry matter, $15.5 \%$ crude protein, and $25 \%$ acid detergent fiber) is a suitable feed source for Spanish (meattype) goats (Wildeus et al., 1995).

Researchers evaluating kenaf as a potential forage crop also determined that the age of plant at harvest can influence plant composition, such as leaf percentages, and protein content (Webber, 1993a; Bhardwaj \& Webber, 1994). The leaf biomass percentage and percent crude protein decreased as the kenaf plant increased in height and maturity. This composition and quality change occurred because the lower leaves senesce, often producing plants at DAP without leaves on the lower one-half to three-quarters of the plant stalk. Webber (1993a) reported leaf biomass percentages decreased from $36.2 \%$ at 76 DAP to $20.2 \%$ for a full season kenaf. Bhardwaj and Webber (1994) determined in a forage evaluation of 6 cultivars that kenaf plant crude protein decreased from $8 \%$ to $5 \%$ between harvests at 70 to 140 DAP. Bhardwaj et al. (1995) examined the prospect of multiple kenaf forage harvests during a single growing season, harvesting kenaf at 85, 92, and 99 DAP and then reharvesting the same plants at 179 DAP. The research demonstrated the feasibility of multiple kenaf harvests, and that kenaf protein during the second harvests was equal to or greater than the first harvests.

Kenaf can also be a beneficial rotational crop or cover crop. Webber (1999) determined that kenaf grown in rotation with soybeans [Glycine $\max$ (L.) Merr., Fabaceae]. Not only did kenaf served as an alternative fiber and feed crop, it also reduced the presence of stunt nematode (Tylenchorhynchus spp.) populations, which benefited the next year's soybean crop. Unfortunately, it has also been determined that kenaf can be allelopathic to other plant species (Russo et al., 1997a, 1997b; Webber et al., 2015a, 2015b). It is unknown whether using kenaf as a rotational crop for sugarcane will detrimentally impact the following sugarcane crop.

\subsection{Cowpea}

Cowpea (Vigna unguiculata L. Walp.) is often used a rotational crop/cover crop because it is a legume crop with the potential to add soil nitrogen (Cherr et al., 2006; Creamer \& Baldwin, 2000; Dabney et al., 2001), increase soil health and tilth (Abdul-Baki et al., 2005; Harrison et al., 2006; Teasdale, 1998; Teasdale \& Abdul-Baki, 1997; Teasdale \& Shirley, 1998), and suppress weeds (Herrero et al., 2001; Hill et al., 2006; Hutchinson \& McGiffen, 2000; McGiffen et al., 2000; Ngouajio \& McGiffen, 2002; Ngouajio et al., 2003; Unamma et al., 1986). As with kenaf, research has also shown that cowpea has exhibited allelopathic activity (Adler \& Chase, 2007; Hill et al., 2007).

\subsection{Objective}

A 2 year experiment was conducted at the USDA, ARS, Sugarcane Research Unit, Houma, LA to determine the impact of cover crop production on sugarcane production. Kenaf and cowpea were chosen as potential rotational cover crops for planting during the fallow period prior to replanting sugarcane. 


\section{Materials and Methods}

\subsection{Cover Crops}

\subsubsection{Kenaf and Cowpea Establishment}

The experiment was conducted at the USDA-ARS Sugarcane Research Unit station in Houma, LA $\left(29^{\circ} 35^{\prime} 2^{\prime \prime} \mathrm{N}\right.$, $90^{\circ} 43^{\prime} 39^{\prime \prime} \mathrm{W}$ ) on a Cancienne silt loam and silty clay loam soils, $0-1 \%$ slope. The experiment included seven treatments; two cover crops, kenaf var. 'Everglades 41' and cowpeas (Vigna unguiculata L. Walp.) var. 'Iron Clay', three FPS harvest treatments for each cover crop, and a control. The experiment had four replications. The three FPS harvest treatments included the removal of the cover crop at 50 days after planting (DAP), the removal of the harvested cover crop at 100 DAP, and lastly, cutting the cover crop at 100 DAP and incorporating the plant material into the soil prior to sugarcane planting (Table 1). The control treatment did not have a cover crop. Prior to planting nitrogen was applied and incorporated at a rate of $90 \mathrm{~kg} / \mathrm{ha}$ (May 8, 2013). The kenaf and cowpeas were planted in 2 rows, $76 \mathrm{~cm}$ spacing, on raised beds $(1.8 \mathrm{~m}$ centers) at a rate 28.4 seeds $/ \mathrm{m}$ on May 8,2013 . A seed inoculant (Rhizobium leguminosarum biovar viceae) was added to the cowpea seed just prior to planting (Johnny's Selected Seeds, Winslow, ME). Each plot contained 3 raised beds ( 2 cover crop rows/bed) and plots were $7.6 \mathrm{~m}$ long. The day following planting, pendimethalin ( $N$-(1-ethylpropyl)-3,4-dimethyl-2,6dinitrobenzenamine) was applied as a pre-emergence herbicide at a rate of $1.06 \mathrm{~kg}$ a.i./ha (May 9, 2013). The annual rainfall for 2013 was $415.0 \mathrm{~mm}$. No additional water was applied.

\subsubsection{Kenaf and Cowpea Harvests}

\section{(1) Kenaf 50-R and Cowpea 50-R}

At 50 DAP (June 27, 2013), the two rows of cover crop in the center $3 \mathrm{~m}$ length on the middle raised bed were harvested to determine the plant population and yields. A 5 plant subsample was collected from each bulk sample. The 5 plants in the subsamples were separated into leaves and stalks, and the fresh and oven dry weight $\left(60{ }^{\circ} \mathrm{C}\right)$ (Webber et al., 2016) determined (Tables 2 and 3). The entire plot area ( 3 raised beds $\times 1.8 \mathrm{~m}$ centers $\times 7.6 \mathrm{~m}$ length) for each 50 DAP cover crop was harvested and the plant material removed from the location.

(2) Kenaf 100-R, Kenaf 100-I, Cowpea 100-R and Cowpea 100-I

At 100 DAP (16 August 2013), the two cover crop rows in the center $3 \mathrm{~m}$ length on the middle raised bed were harvested at ground level to determine the plant population and yields. A 5 plant subsample was collected from each bulk sample. The 5 plants in the subsamples were separated into leaves and stalks, and the fresh and oven dry weight $\left(60^{\circ} \mathrm{C}\right)$ determined (Tables 2 and 3). The entire plot area ( 3 raised beds $\times 1.8 \mathrm{~m}$ centers $\times 7.6 \mathrm{~m}$ length) for each 100 DAP cover crop was harvested. The plant material for the Kenaf 100-R and Cowpea 100-R were then removed from the entire plot area ( 3 raised beds $\times 1.8 \mathrm{~m}$ centers $\times 7.6 \mathrm{~m}$ length), while the plant material for the Kenaf 100-I and Cowpea 100-I plots was left in place to be soil incorporated prior to planting the sugarcane.

\subsection{Sugarcane}

\subsubsection{Sugarcane Establishment}

Sugarcane variety HoCP 96-540 was planted on August 26, 2013, 110 days after planting the cover crops, $60 \mathrm{~d}$ after harvesting the 50 DAP cover crops, and $10 \mathrm{~d}$ after harvesting the 100 DAP cover crops. The HoCP 96-540 (Tew et al., 2005a) seed cane was planted with whole stalk cane, 3 stalks with a $10 \%$ overlap. The sugarcane was then covered $(8 \mathrm{~cm})$ and a roller-press was used to secure the raised beds and provide good soil to seed cane contact. A tank-mix containing metribuzin (4-amino-6-tert-butyl-4,5-dihydro-3-methylthio-1,2,4-triazin-5-one) at $3.4 \mathrm{~kg}$ a.i./ha and pendimethalin at $2.2 \mathrm{~kg}$ a.i./ha was broadcast immediately after planting for weed control. Standard sugarcane production practices were used throughout the summer and fall of 2013, and spring and summer of 2014. Plots were fertilized by side-dressing with $112 \mathrm{~kg} / \mathrm{ha} \mathrm{N}, 15 \mathrm{~kg} / \mathrm{ha} \mathrm{P}$, and $55 \mathrm{~kg} / \mathrm{ha} \mathrm{K}$. Annual rainfall for 2014 was $397.5 \mathrm{~mm}$. Plots were not irrigated.

\subsubsection{Sugarcane Harvest}

Following millable stalk population $(>1.4 \mathrm{~m}$ ) determination, 15 sugarcane stalks were randomly harvested from each plot on 17 November 2014. The total fresh weight of the 15 whole stalk bundles were measured prior to cutting the stalks in billet for processing in a prebreaker (Model 702, Cameco Industries, Inc., Thibodaux, LA). A $1000 \mathrm{~g}$ sample of the chopped sugarcane was then placed in a press (Model 703, Cameco Industries, Inc., Thibodaux, LA) to extract the juice for theoretical recoverable sucrose (TRS), which was estimated by the product of Brix by using a refractometer and pol \% sucrose by direct polarization (Meade \& Chen, 1977; Johnson \& Richard, 2005). Sucrose yield (kg/ha) was calculated as the product of sugarcane yields and TRS 
(White et al., 2010). All data were subjected to ANOVA and mean separation using LSD with $\mathrm{P}=0.05$ (SAS Inc., SAS, Ver. 9.0, Cary, NC).

Table 1. Treatment Table: Experimental cover crop treatments prior to planting the primary sugarcane crop

\begin{tabular}{|c|c|c|c|c|}
\hline Cover Crop Treatment & Harvest Date DAP & $\begin{array}{l}\text { Cover Crop Handling }{ }^{\mathrm{Y}} \\
\text { (Removed or Incorporated) }\end{array}$ & Primary Crop & Treatment Code \\
\hline Kenaf & 50 & Removed $^{\prime \prime}$ & Sugarcane & Kenaf 50-R \\
\hline Kenaf & 100 & Removed & Sugarcane & Kenaf 100-R \\
\hline Kenaf & 100 & Incorporated $^{\mathrm{W}}$ & Sugarcane & Kenaf $100-\mathrm{I}$ \\
\hline Cowpea & 50 & Removed & Sugarcane & Cowpea 50-R \\
\hline Cowpea & 100 & Removed & Sugarcane & Cowpea 100-R \\
\hline Cowpea & 100 & Incorporated & Sugarcane & Cowpea 100-I \\
\hline Control (Fallow) & - & - & Sugarcane & Control \\
\hline
\end{tabular}

Note. ${ }^{\mathrm{Z}} \mathrm{DAP}=$ Days After Planting; ${ }^{\mathrm{Y}}$ Cover Crop Handling (Removed or Incorporated) $=$ Cover crops $(\mathrm{kenaf}$ and cowpea) were either harvested at ground level and removed or harvested, left in place, and incorporated prior to planting the sugarcane; ${ }^{\mathrm{X}}$ Removed $=$ Cover crop was harvested and removed; ${ }^{\mathrm{W}}$ Incorporated $=$ Cover crop was harvested and incorporated in place prior to sugarcane planting.

\section{Results and Discussion}

\subsection{Cover Crop Yields}

The harvest dates, 50 DAP vs. 100 DAP, significantly influenced the yield and plant partitioning for both cover crops across all parameters measured (Tables 2 and 3). The impact for DAP harvesting for kenaf was consistent across the yield and plant partitioning (Tables 2 and 3). Kenaf fresh and dry yields, for the leaves, stalks, and whole plants, increased from the 50 to 100 DAP (Tables 2 and 3). The kenaf moisture content (\% moisture) consistently decreased for the leaves, stalks and whole plant from 50 to 100 DAP (Table 3), while the percentage the fresh and dry weight of the leaves decreased and the percentage of fresh and dry weight of the stalks increased on the whole plant basis (Table 3).

Cowpea, in most aspects, followed a similar trend as kenaf as influenced by DAP harvests (Tables 2 and 3 ) with the exception of the cowpea leaf fresh and dry weights (Table 2). Unlike kenaf, the cowpea leaf, fresh and dry weight yields (50 DAP), 19.4 and $2.5 \mathrm{mt} / \mathrm{ha}$, respectively, decreased to 17.0 and $2.4 \mathrm{mt} / \mathrm{ha}$ (100 DAP) (Table 4). Although, it is not unexpected for the leaf weight percentage to decrease on the whole plant basis, this does not typically result in a decrease in total leaf yield. Perhaps, it was the natural decrease in cowpea plant population from 264,000 plants/ha (50 DAP) to 208,000 plants/ha (100 DAP) (Table 3). This $21 \%$ decrease in plant population may have been partially responsible for the slight decrease in leaf yields, while still producing a $40 \%$ increase in whole plant yields from 4.1 to $5.9 \mathrm{mt} / \mathrm{ha}, 50 \mathrm{DAP}$ and $100 \mathrm{DAP}$, respectively (Table 2). As is typical for kenaf, intra-crop competition can reduce plant populations, as seen in the $6.5 \%$ reduction in the kenaf plant population from 323,000 (50 DAP) to 302,000 plants/ha (100 DAP) (Table 3) (Maina et al., 2002). Unlike the cowpea, where the whole plant dry weights only increased from 4.1 to $5.9 \mathrm{mt} / \mathrm{ha}$, a $44 \%$ increase above the 50 DAP (Table 3), the kenaf whole plant dry weights increased from 4.4 to $15.0 \mathrm{mt} / \mathrm{ha}$, a $241 \%$ increase (Table 3). The majority of the kenaf whole dry weigh increase, $10.6 \mathrm{mt} / \mathrm{ha}$, was the result of the $9.6 \mathrm{mt} / \mathrm{ha}$ increase in stalk dry weights, $2.7 \mathrm{mt} / \mathrm{ha} \mathrm{(50} \mathrm{DAP)} \mathrm{to} 12.3 \mathrm{mt} / \mathrm{ha} \mathrm{(100} \mathrm{DAP)} \mathrm{(Table} \mathrm{2).}$

The differences in plant morphology for kenaf and cowpeas become obvious as the plant partitioning differences are compared at 100 DAP (Table 3). On the whole plant basis, the kenaf stalk dry weight percentages are $82 \%$ compared to only $59 \%$ for the cowpea (Table 3 ). The differences observed when comparing these two cover crops is probably due to a large extent explained by the breeding programs which selected them for different intended end uses, fiber (kenaf) and forage (cowpea). The kenaf variety 'Everglades 41' was specially developed for stalk production over that of leaf production, whereas the cowpea variety 'Iron and Clay' was developed for its nitrogen production as a forage or green manure crop. As Everglades 41 develops past the 50 DAP maturity level at population similar as those in this study, the plant tends to produce a single erect stalk with the lower leaves abscising as new leaves are produced higher on the plant's stalk. This growth habit results in a slower rate of dry leaf accumulation compared to a greater rate of stalk dry weight accumulation (Tables 2 and 3 ). 
Table 2. Impact of harvest date, days after planting (DAP), on cover crop (kenaf and cowpea) yields

\begin{tabular}{|c|c|c|c|c|c|c|c|}
\hline \multirow[b]{2}{*}{ Cover Crop \& DAP } & \multirow{2}{*}{$\begin{array}{l}\text { Leaves } \\
\text { Fresh } \\
\text { Weight }\end{array}$} & \multirow{2}{*}{$\begin{array}{l}\text { Leaves } \\
\text { Dry } \\
\text { Weight }\end{array}$} & \multirow{2}{*}{$\begin{array}{l}\text { Stalk } \\
\text { Fresh } \\
\text { Weight }\end{array}$} & \multirow{2}{*}{$\begin{array}{l}\text { Stalk } \\
\text { Dry } \\
\text { Weight }\end{array}$} & \multicolumn{3}{|c|}{ Whole Plant (Leaves \& Stalks) } \\
\hline & & & & & $\begin{array}{l}\text { Fresh } \\
\text { Weight }\end{array}$ & $\begin{array}{l}\text { Dry } \\
\text { Weight }\end{array}$ & Plant Pop. \\
\hline & --mt/ha-- & --mt/ha-- & --mt/ha-- & --mt/ha-- & --mt/ha-- & --mt/ha-- & --plts/ha-- \\
\hline Kenaf $50-\mathrm{R}^{\mathrm{Y}}$ & $10.4 \mathrm{c}^{\mathrm{W}}$ & $1.7 \mathrm{c}$ & $17.4 \mathrm{c}$ & $2.7 \mathrm{c}$ & $27.8 \mathrm{~d}$ & $4.4 \mathrm{c}$ & $322,910 \mathrm{a}$ \\
\hline Kenaf $100-\mathrm{R}$ & $15.4 \mathrm{~b}$ & $2.7 \mathrm{a}$ & $51.0 \mathrm{a}$ & $12.3 \mathrm{a}$ & $66.4 \mathrm{a}$ & $15.0 \mathrm{a}$ & $302,280 \mathrm{~b}$ \\
\hline Kenaf $100-\mathrm{I}^{\mathrm{X}}$ & $15.4 \mathrm{~b}$ & $2.7 \mathrm{a}$ & $51.0 \mathrm{a}$ & $12.3 \mathrm{a}$ & $66.4 \mathrm{a}$ & $15.0 \mathrm{a}$ & $302,280 \mathrm{~b}$ \\
\hline Cowpea 50-R & $19.4 \mathrm{a}$ & $2.5 \mathrm{~b}$ & $14.0 \mathrm{~d}$ & $1.6 \mathrm{~d}$ & $33.5 \mathrm{c}$ & $4.1 \mathrm{c}$ & $263,710 \mathrm{c}$ \\
\hline Cowpea $100-\mathrm{R}$ & $17.0 \mathrm{~b}$ & $2.4 \mathrm{~b}$ & $21.4 \mathrm{~b}$ & $3.5 \mathrm{~b}$ & $38.4 \mathrm{~b}$ & $5.9 \mathrm{~b}$ & $207,649 \mathrm{~d}$ \\
\hline Cowpea 100-I & $17.0 \mathrm{~b}$ & $2.4 \mathrm{~b}$ & $21.4 \mathrm{~b}$ & $3.5 \mathrm{~b}$ & $38.4 \mathrm{~b}$ & $5.9 \mathrm{~b}$ & $207,649 \mathrm{~d}$ \\
\hline
\end{tabular}

Note. ${ }^{\mathrm{Z}} \mathrm{DAP}=$ Days After Planting; ${ }^{\mathrm{Y}} \mathrm{R}=$ Removed $=$ Cover crop was harvested and removed; ${ }^{\mathrm{X}} \mathrm{I}=$ Incorporated $=$ Cover crop was harvested and incorporated in place prior to sugarcane planting; ${ }^{\mathrm{W}}$ Means in a column followed by the same lower case letter are not significantly different at $\mathrm{P} \leq 0.05$, ANOVA.

Table 3. Impact of harvest date (DAP) on cover crop plant moisture and partitioning

\begin{tabular}{|c|c|c|c|c|c|c|c|}
\hline \multirow[b]{2}{*}{ Cover Crop \& $\mathrm{DAP}^{Z}$} & \multicolumn{3}{|c|}{ Leaves } & \multicolumn{3}{|c|}{ Stalks } & \multirow{2}{*}{$\begin{array}{l}\text { Total } \\
\text { Moisture } \\
\text { Content }\end{array}$} \\
\hline & $\begin{array}{l}\text { Fresh } \\
\text { Weight }\end{array}$ & $\begin{array}{l}\text { Moisture } \\
\text { Content }\end{array}$ & $\begin{array}{l}\text { Dry } \\
\text { Weight }\end{array}$ & $\begin{array}{l}\text { Fresh } \\
\text { Weight }\end{array}$ & $\begin{array}{l}\text { Moisture } \\
\text { Content }\end{array}$ & $\begin{array}{l}\text { Dry } \\
\text { Weight }\end{array}$ & \\
\hline & $\%$ & $\%$ & $\%$ & $\%$ & $\%$ & $\%$ & $\%$ \\
\hline Kenaf $50-\mathrm{R}^{\mathrm{Y}}$ & $37.4 \mathrm{c}^{\mathrm{W}}$ & $83.5 \mathrm{bc}$ & $39.2 \mathrm{~b}$ & $62.6 \mathrm{~b}$ & $84.7 \mathrm{~b}$ & $60.8 \mathrm{~b}$ & $84.2 \mathrm{~b}$ \\
\hline Kenaf $100-\mathrm{R}$ & $23.2 \mathrm{~d}$ & $82.6 \mathrm{c}$ & $17.8 \mathrm{c}$ & $76.9 \mathrm{a}$ & $75.8 \mathrm{c}$ & $82.2 \mathrm{a}$ & $77.4 \mathrm{c}$ \\
\hline Kenaf $100-\mathrm{I}^{\mathrm{X}}$ & $23.2 \mathrm{~d}$ & $82.6 \mathrm{c}$ & $17.8 \mathrm{c}$ & $76.9 \mathrm{a}$ & $75.8 \mathrm{c}$ & $82.2 \mathrm{a}$ & $77.4 \mathrm{c}$ \\
\hline Cowpea 50-R & $58.1 \mathrm{a}$ & $87.1 \mathrm{a}$ & $61.2 \mathrm{a}$ & $41.9 \mathrm{~d}$ & $88.6 \mathrm{a}$ & $38.8 \mathrm{c}$ & $87.7 \mathrm{a}$ \\
\hline Cowpea 100-R & $44.3 \mathrm{~b}$ & $85.2 \mathrm{ab}$ & $40.7 \mathrm{~b}$ & $55.7 \mathrm{c}$ & $82.7 \mathrm{~b}$ & $59.4 \mathrm{~b}$ & $83.9 \mathrm{~b}$ \\
\hline Cowpea 100-I & $44.3 \mathrm{~b}$ & $85.2 \mathrm{ab}$ & $40.7 \mathrm{~b}$ & $55.7 \mathrm{c}$ & $82.7 \mathrm{~b}$ & $59.4 \mathrm{~b}$ & $83.9 \mathrm{~b}$ \\
\hline
\end{tabular}

Note. ${ }^{\mathrm{Z}} \mathrm{DAP}=$ Days After Planting; ${ }^{\mathrm{Y}} \mathrm{R}=$ Removed $=$ Cover crop was harvested and removed; ${ }^{\mathrm{X}} \mathrm{I}=$ Incorporated $=$ Cover crop was harvested and incorporated in place prior to sugarcane planting; ${ }^{\mathrm{W}}$ Means in a column followed by the same lower case letter are not significantly different at $\mathrm{P} \leq 0.05$, ANOVA.

\subsection{Sugarcane Yields}

The cover crops (kenaf and cowpea) and their harvest options (50-R, 100-R, and 100-I) did not adversely impact or benefit the sugarcane millable stalk populations (millable stalks/ha) when compared to the control treatment (no cover crop) (Table 4). The sugarcane millable stock populations were significantly greater when comparing the Cowpea 100-R (100 DAP + Removial), 107,637 plants/ha compared to Kenaf 100-I (100 DAP + Incorporated), 82,971 millable stalks/ha (Table 4).

There were no significant differences between the cover crop treatments and the control treatment, or among any of the cover crop treatments for sugarcane yields ( $\mathrm{mt} / \mathrm{ha}$ ) (Table 4). Sugarcane yields averaged $112 \mathrm{mt} / \mathrm{ha}$ across all the treatments with a range of $103 \mathrm{mt} / \mathrm{ha}$ for the Kenaf $100-\mathrm{I}$ treatment to $117 \mathrm{mt} / \mathrm{ha}$ for the Cowpea $100-\mathrm{R}$ treatment, with the control producing $113 \mathrm{mt} / \mathrm{ha}$ (Table 4).

The cover crop treatments did not adversely impact or benefit the sugarcane total recoverable sugar (TRS) when compared to the control treatment (Table 4). The TRS for Kenaf $50-\mathrm{R}(120 \mathrm{~kg} / \mathrm{mt})$ was significantly greater than either Cowpea 50-R $(111 \mathrm{~kg} / \mathrm{mt})$ and Cowpea $100-\mathrm{I}(112 \mathrm{~kg} / \mathrm{mt})$ treatments.

There were no significant differences between the cover crop treatments and the control, or among the cover crop treatments for sugar yields $(\mathrm{kg} / \mathrm{ha})$. Sugar yields averaged $12,841 \mathrm{~kg} / \mathrm{ha}$ across experimental treatments, with a range from 11,708 kg/ha (Kenaf 100-I) to 13,683 kg/ha (Kenaf 50-R). The control produced 13,014 kg/ha (Table 4). 
Table 4. Impact of cover crop treatments on sugarcane yield parameters

\begin{tabular}{lllll}
\hline Cover Crop \& DAP & $\begin{array}{l}\text { Millable Stalk } \\
\text { Population }\end{array}$ & Sugarcane Yield & $\begin{array}{l}\text { Total Recoverable } \\
\text { Sucrose }\end{array}$ & Sugar Yield \\
\hline \multirow{2}{*}{ Kenaf 50-R } & stalks/ha & $\mathrm{mt} / \mathrm{ha}$ & $\mathrm{kg} / \mathrm{mt}$ & $\mathrm{kg} / \mathrm{ha}$ \\
Kenaf 100-R & $96,426 \mathrm{abc}^{\mathrm{V}}$ & $113.6 \mathrm{a}$ & $120.5 \mathrm{a}$ & $13,683 \mathrm{a}$ \\
Kenaf 100-I & $96,426 \mathrm{abc}$ & $116.9 \mathrm{a}$ & $113.2 \mathrm{ab}$ & $13,238 \mathrm{a}$ \\
Cowpea 50-R & $82,971 \mathrm{c}$ & $102.0 \mathrm{a}$ & $114.8 \mathrm{ab}$ & $11,708 \mathrm{a}$ \\
Cowpea 100-R & $92,838 \mathrm{abc}$ & $107.9 \mathrm{a}$ & $111.4 \mathrm{~b}$ & $12,023 \mathrm{a}$ \\
Cowpea 100-I & $107,637 \mathrm{a}$ & $117.0 \mathrm{a}$ & $112.8 \mathrm{ab}$ & $13,200 \mathrm{a}$ \\
Control (Fallow) & $99,564 \mathrm{ab}$ & $116.2 \mathrm{a}$ & $112.1 \mathrm{~b}$ & $13,019 \mathrm{a}$ \\
\hline
\end{tabular}

Note. ${ }^{\mathrm{Z}} \mathrm{DAP}=$ Days After Planting; ${ }^{\mathrm{Y}} \mathrm{R}=$ Removed $=$ Cover crop was harvested and removed; ${ }^{\mathrm{X}} \mathrm{I}=$ Incorporated $=$ Cover crop was harvested and incorporated in place prior to sugarcane planting; ${ }^{\mathrm{W}}$ Total Recoverable Sucrose $=$ TRS; ${ }^{\vee}$ Means in a column followed by the same lower case letter are not significantly different at $\mathrm{P} \leq 0.05$, ANOVA.

\section{Conclusions}

Although the kenaf cover-crop treatment 50 DAP did produce greater TRS $(120 \mathrm{~kg} / \mathrm{mt})$ compared the Cowpea 50-R DAP treatment $(111 \mathrm{~kg} / \mathrm{mt})$ and the Cowpea 100-I DAP $(112 \mathrm{~kg} / \mathrm{ha})$, none of the cover crop treatments were significantly better or worse than the control, which had no cover crop. The Kenaf 100-I treatment (kenaf incorporation after $100 \mathrm{DAP}$ ) may present potential problems related to allelopathy as indicated by the trend of decreased sugarcane millable stalk populations (Webber et al., 2015a, 2015b). The incorporation of the kenaf certainly didn't provide any positive trends for the sugarcane production factors. The results demonstrate the potential use of these alternative cover crops during the fallow period prior to planting sugarcane, especially in the case of kenaf if it is removed for other uses, without adversely affecting the plant cane yields.

\section{References}

Abdul-Baki, A. A., Klassen, W., Bryan, H. H., Codallo, M., Hima, B., Wang, Q. R., ... Handoo, Z. (2005). A biologically-based system for winter production of fresh-market tomatoes in South Florida. Proc. Fla. State Hort. Soc., 118, 153-159.

Adler, M. J., \& Chase, C. A. (2007). Comparison of the allelopathic potential of leguminous summer cover crops: Cowpea, sunn hemp, and velvetbean. HortScience, 42(2), 289-293.

Bhardwaj, H. L., \& Webber III, C. L. (1994). Seasonal variation in kenaf yield and quality. Proc. Int. Kenaf Assoc. Conf., 6, 150-154.

Bhardwaj, H. L., Rangappa, M., \& Webber III, C. L. (1995). Potential of kenaf as a forage. Proc. Int. Kenaf Assoc. Conf., 7, 95-103.

Cherr, C. M., Scholberg, J. M. S., \& McSorley, R. (2006). Green manure approaches to crop production: A synthesis. Agron. J., 98, 302-319. http://dx.doi.org/10.2134/agronj2005.0035

Clark, T. F., \& Wolff, I. A. (1969). A search for new fiber crops, XI. Compositional characteristics of Illinois kenaf at several population densities and maturities. TAPPI, 52(11), 211-216.

Creamer, N. G., \& Baldwin, K. R. (2000). An evaluation of summer cover crops for use in vegetable production systems in North Carolina. HortScience, 35, 600-603.

Dabney, S. M., Delgado, J. A., \& Reeves, D. W. (2001). Using winter cover crops to improve soil and water quality. Commun. Soil Sci. Plant Anal., 32, 1221-1250. http://dx.doi.org/10.1081/CSS-100104110

Dempsey, J. M. (1975). Fiber Crops. The Univ. Presses of Florida, Gainesville.

Harrison, H. F., Jackson, D. M., Keinath, A. P., Marino, P. C., \& Pullaro, T. (2004). Broccoli production in cowpea, soybean, and velvetbean cover crop mulches. HortTech., 14, 484-487.

Herrero, E. V., Mitchell, J. P., Lanini, W. T., Temple, S. R., Miyao, E. M , Morse, R. D., \& Campiglia, E. (2001). Use of cover crop mulches in a no-till furrow-irrigated processing tomato production. HortTech, 11, 43-48.

Hill, E. C., Ngouajio, M., \& Nair, M. G. (2006). Differential response of weeds and vegetable crops to aqueous extracts of hairy vetch and cowpea. HortSci., 41, 695-700. 
Hill, E. C., Ngouajio, M., \& Nair, M. G. (2007). Allelopathic potential of hairy vetch (Vicia villosa) and cowpea (Vigna unguiculata) methanol and ethyl acetate extracts on weeds and vegetables. Weed Tech., 21(2), 437-444. http://dx.doi.org/10.1614/WT-06-167.1

Hutchinson, C. M., \& McGiffen, M. E. Jr. (2000). Cowpea cover crop mulch for weed control in desert pepper production. HortSci., 35, 196-198.

Johnson, R. M., \& Richard Jr., E. P. (2005). Sugarcane yield, sugarcane quality, and soil variability in Louisiana. Agron J., 97(3), 760-771. http://dx.doi.org/10.2134/agronj2004.0184

Killinger, G. B. (1969). Kenaf (Hibiscus cannabinus L.), a multi-use crop. Agron. J., 61, 734-736. http://dx.doi.org/10.2134/agronj1969.00021962006100050025x

Maina, G. G., Brown, J. S., \& Gersani, M. (2002). Intra-plant versus inter-plant root competition in beans: avoidance, resource matching or tragedy of the commons. Plant Ecol., 160(2), 235-247. http://dx.doi.org/10.1023/A:1015822003011

McGiffen Jr., M. E., Ehler, J. D., \& Aguiar, J. L. (2000). Introduction to organic horticulture colloquium. HortTech., 10, 661-662.

Meade, G. P., \& Chen, J. C. P. (1977). In G. P. Meade \& J. C. P. Chen (Eds.), Cane Sugar Handbook (p. 947). Wiley, New York.

Nelson, G. H., Nieschlag, H. J., \& Wolff, I. A. (1962). A search for new fiber crops, V. Pulping studies on kenaf. TAPPI, 45(10), 780-786.

Ngouajio, M., \& McGiffen, M. E. (2002). Going organic changes weed population dynamics. HortTech., 12, 590-596.

Ngouajio, M., McGiffen Jr., M. E., \& Hutchinson, C. M. (2003). Effect of cover crop and management system on weed populations in lettuce. Crop Protection, 22(1), 57-64. http://dx.doi.org/10.1016/S0261-2194 (02)00111-4

Nieschlag, H. J., Nelson, G. H., Wolff, I. A., \& Perdue, R. E. Jr. (1960). A search for new fiber crops. TAPPI, 43, 193-201.

Russo, V. M., Cartwright, C., \& Webber III, C. L. (1997a). Mulching effects on erosion of soil beds and on yield of autumn and spring planted vegetables. Biological Agriculture and Horticulture, 14, 85-93. http://dx.doi.org/10.1080/01448765.1997.9754799

Russo, V. M., Webber III, C. L., \& Myers, D. L. (1997b). Kenaf extract affects germination and post-germination development of weed, grass and vegetable seeds. Ind. Crops Prod., 6, 59-69. http://dx.doi.org/10.1016/S0926-6690(96)00206-3

Suriyajantratong, W., Tucker, R. E., Sigafus, R. E., \& Mitchell Jr., G. E. (1973). Kenaf and rice straw for sheep. J. Anim. Sci., 37, 1251-1254.

Swingle, R. S., Urias, A. R., Doyle, J. C., \& Voigt, R. L. (1978). Chemical composition of kenaf forage and its digestibility by lambs and in vitro. J. Anim. Sci., 46, 1346-1350.

Teasdale, J. R. (1998). Cover crops, smother plants, and weed management. In J. L. Hatfield, D. D. Buhler, \& B. A. Stewart (Eds.), Integrated weed and soil management (pp. 247-270). Ann Arbor Press, Chelsea, Mich.

Teasdale, J. R., \& Abdul-Baki, A. (1997). Growth analysis of tomatoes in black polyethylene and hairly vetch production systems. HortSci., 32, 659-663.

Teasdale, J. R., \& Shirley, D. W. (1998). Influence of herbicide application timing on corn production in a hairy vetch cover crop. J. prod. Agr., 11, 121-125. http://dx.doi.org/10.2134/jpa1998.0121

Tew, T. L., White, W. H., Legendre, B. L., Grisham, M. P., Dufrene, E. O., Garrison, D. D., ... Miller, J. D. (2005). Registration of 'HoCP 96-540' Sugarcane. Crop Sci., 45(2), 785-786. http://dx.doi.org/10.2135/ cropsci2005.0785a

Unamma, R. P. A., Ene, L. S. O., Odurukwe, S. O., \& Enyinnia, T. (1986). Integrated weed management for cassava intercropped with maize. Weed Res., 26, 9-17. http://dx.doi.org/10.1111/j.1365-3180.1986. tb00671.x

Webber III, C. L. (1993). Crude protein and yield components of six kenaf cultivars as affected by crop maturity. Ind. Crops Prod., J., 2, 27-31. http://dx.doi.org/10.1016/0926-6690(93)90007-V 
Webber III, C. L. (1999). Effect of kenaf and soybean rotations on yield components. In J. Janick (Ed.), Perspectives on new crops and new uses (pp. 316-322). ASHS Press, Alexandria, VA.

Webber III, C. L., \& Bledsoe, R. E. (1993). Kenaf: Production, harvesting, and products. In J. Janick \& J. E. Simon (Eds.), New Crops (pp. 416-421). New York: Wiley.

Webber III, C. L., Bhardwaj, H. L., \& Bledsoe, V. K. (2002). Kenaf production: Fiber, feed, and seed. In J. Janick \& A. Whipkey (Eds.), Trends in new crops and new uses (pp. 327-339). ASHS Press, Alexandria, VA.

Webber III, C. L., White Jr., P. M., Myers, D. L., Shrefler, J. W., \& Taylor, M. J. (2015a). Kenaf (Hibiscus cannabinus L.) impact on post-germination seedling growth. J. of Agricultural Science, 7(12), 91-99. http://dx.doi.org/10.5539/jas.v7n12p91

Webber III, C. L., White, P. M. Jr., Myers, D. L., Taylor, M. J., \& Shrefler, J. W. (2015b). Impact of kenaf (Hibiscus cannabinus L.) leaf, bark, and core extracts on germination of five plant species. $J$. of Agricultural Science, 7(2), 93-98. http://dx.doi.org/10.5539/jas.v7n2p93

Webber III, C. L., White, P. M. Jr., Petrie, E. C., Shrefler, J. W., \& Taylor, M. J. (2016). Sugarcane Bagasse Ash as a Seedling Growth Media Component. J. of Agricultural Science, 8(1), 1-7. http://dx.doi.org/10.5539/jas.v8n1p1

White, G. A., Cummins, D. G., Whiteley, E. L., Fike, W. T., Greig, J. K., Martin, J. A., ... Clark, T. F. (1970). Cultural and harvesting methods for kenaf. USDA Prod. Res. Rpt., 113. Washington, DC.

White, P. M. Jr., Viator, R. P., \& Richard, E. P. Jr. (2010). Sugarcane yield responses of four cultivars to three planting dates in Louisiana. J. American Soc. Sugar Cane Technologist, 30, 115-132.

Wildeus, S., Bhardwaj, H. L., Rangappa, M., \& Webber III, C. L. (1995). Consumption of chopped kenaf by Spanish goats. Proc. Int. Kenaf Assoc. Conf., 7, 161-164.

Wilson, F. D., Summers, T. E., Joyner, J. F., Fishler, D. W., \& Seale, C. C. (1965). 'Everglades 41' and 'Everglades 71', two new cultivars of kenaf (Hibiscus cannabinus L.) for the fiber and seed. Florida Agr. Expt. Sta. Cir. S-168.

Wing, J. M. (1967). Ensilability, acceptability and digestibility of kenaf. Feedstuffs, 39, 26.

\section{Copyrights}

Copyright for this article is retained by the author(s), with first publication rights granted to the journal.

This is an open-access article distributed under the terms and conditions of the Creative Commons Attribution license (http://creativecommons.org/licenses/by/4.0/). 